to look in. Harry Partch, Hobo Composer is a history of how one composer, inconveniently if not quixotically original, positioned himself to get his music made and to get taken seriously by his peers. In Granade's telling, it is also, by extension, a portrait of America between the wars, as refracted through an artist determined to transmit the American experience purely as he found it.

KYLE GANN <gann@bard.edu>

Twentieth-Century Music 12/2, 274-279 @ Cambridge University Press, 2015 doi: $10.1017 / S 1478572215000080$

\title{
Ruth Feldstein, How It Feels to Be Free: Black Women Entertainers and the Civil Rights Movement (New York: Oxford University Press, 2013), ISBN 978-0-19-531403-8 (hb).
}

Anyone familiar with the body of scholarship on the Civil Rights Movement has witnessed the considerable growth that has taken place in the last decade in documenting the role of women activists. This historiography is defined in a myriad of genres including compendiums of oral histories such as Hands on the Freedom Plow: Personal Accounts by Women in SNCC, critical studies that contextualize black women in the larger struggle for freedom such as Freedom's Daughters: The Unsung Heroines of the Civil Rights Movement from 1830 to 1970, and articles such as Belinda Robnett's 'African-American Women in the Civil Rights Movement, 19541965: Gender, Leadership, and Micromobilization.' ${ }^{1}$ Recently this body of literature has also come to include works that historicize how black women musicians and entertainers engaged in mediating the rhetoric of civil rights and social justice. ${ }^{2}$ Ruth Feldstein's recent monograph How It Feels to Be Free: Black Women Entertainers and the Civil Rights Movement extends the theoretical perspective of this historiography even further through its exploration of the life narratives and professional activities of five black women performer-activists: Abbey Lincoln, Miriam Makeba, Nina Simone, Diahann Carroll, and Cicely Tyson. Feldstein's narrative

1 For more information on the role of women in the Civil Rights movement see Hands on the Freedom Plow: Personal Accounts By Women in SNCC, ed. Faith S. Holsaert, Martha Prescod, Norman Noonan, Judy Richardson, Betty Garman Robinson, Jean Smith Young and Dorothy M. Zellner (Urbana: University of Illinois Press, 2010); Lynne Olson, Freedom's Daughters: The Unsung Heroines of the Civil Rights Movement from 1830 to 1970 (New York: Simon and Schuster, 2001); Women in the Civil Rights Movement: Trailblazers and Torchbearers, 1941-1965, ed. Vicki L. Crawford, Jacqueline Anne Rouse, and Barbara Woods (Brooklyn: Carlson Publishing, 1990); Belinda Robnett, 'African-American Women in the Civil Rights Movement, 1954-1965: Gender, Leadership, and Micromobilization', The American Journal of Sociology 101/6 (1996), 1661-93; Rachel L. Einwohner, Jocelyn A. Hollander, and Toska Olson, 'Engendering Social Movements: Cultural Images and Movement Dynamics', Gender and Society 14/5 (2000), 679-99.

2 Sources that have addressed this have covered a number of different genres; some representative examples are Gayle Murchison, 'Mary Lou Williams's Hymn "Black Christ of the Andes (St. Martin De Porres)": Vatican II, Civil Rights and Jazz', Musical Quarterly 86/4 (2002), 591-629; Tammy L. Kernodle “"I Wish I Knew How It Would Feel to Be Free": Nina Simone and the Redefining of the Freedom Song of the 1960s', Journal of the Society for American Music 2/3 (August 2008), 295-317; Bernice Johnson Reagon, 'Let the Church Sing “Freedom”, Black Music Research Journal 7 (1987), 105-18; Ingrid Monson, 'Abbey Lincoln's Straight Ahead: Jazz in the Era of the Civil Rights Movement', in Between Resistance and Revolution: Cultural Politics and Social Protest, ed. Richard G. Fox and Orin Starn (New Brunswick: Rutgers University Press, 1997), 171-95. 
interrogates thoroughly how each of these women used the evolutionary changes of the culture industry's engagement with black cultural forms to precipitate more expansive public dialogues about racial and gender equality during the period from the late 1950s into the late 1970s. It thoroughly analyses each woman's uniquely layered and deliberate performance strategies as they engaged with the various media that framed their artistic work - live performances, recordings, cinematic and television performances. In structuring the book in this manner, the author from the very first chapter situates these five women in a historical trajectory of female artist-activists who have engaged in the process of creating black-centred 'agitprop'. This trajectory stretches back to Harriet Tubman's use of spirituals during the US Civil War era, extends to Billie Holiday's historic performances of 'Strange Fruit' at Café Society in the late 1930s, and spreads to Nina Simone's angry but poignant 'Mississippi Goddam' in the 1960s. In the case of Harriet Tubman, her use of the spirituals as a primary communication tool for helping her navigate slaves through the Underground Railroad transformed these songs from their principal association with the ritualistic worship practices of southern black people. Through Tubman, these songs were altered into a theologically centred narrative of resistance against the brutalities of slavery and rebutted claims for slavery's economic value, which had perpetuated its continual growth in the South during the early nineteenth century. These songs and their adoption into the Abolitionist movement can be read as one of the factors that triggered the call for a politically orchestrated dismantling of slavery. If we accept this reading of Tubman and her relationship with the spiritual, then her role in advancing a type of nineteenth-century black female-centred agitprop is twofold: first, it provoked public discussions about America and its promotion of slavery while simultaneously proclaiming a rhetoric of democracy to the rest of the world; and, second, it served - alongside pamphlets and newspaper editorials - as one of the media through which the propaganda of the Abolitionist movement was transmitted. This type of analysis directly correlates with how the musical and theatrical performances of Simone, Lincoln, Makeba, Tyson, and Carroll are considered by Feldstein. One example of this can be gleaned from Chapter 2, 'Africa's Musical Ambassador', which explores among many things Miriam Makeba's performances of black South African folk songs in their native dialects. While Makeba made no direct political statements during the early years of her career in America, her performances provoked larger questions regarding African culture, identity, and politics. More importantly, her engagement with traditional folk culture - while projecting a stage presence that emphasized the natural beauty of the African woman signified Makeba's transformation from 'Lady of Song' to 'Mama Africa' during the early 1960s. As Feldstein asserts:

By engaging her audiences, she did not simply assent to the assumption that the sounds that came out of her mouth were 'weird'. Instead, the 'fascinating and exotic' woman destabilized assumptions about who and what were fascinating and exotic. In doing so, she raised questions about who was the 'we' and who was the 'they'. (70)

This historical trajectory is emphasized throughout the text, but is also used as a means of dismantling the trope of isolation that is often conveyed in the writing of historical narratives. For Feldstein two factors link the activism and art of these performers: their political/social 
participation in the subcultures of Harlem and Greenwich Village and their engagement with the artistic and political legacy of Lena Horne. By positioning Horne as one of the figures who bridged two generations of black women who had advanced racial and gender politics through their musical and cinematic performance, How it Feels to Be Free situates itself theoretically with other works that have advanced similar ideas. ${ }^{3}$ But where other works focus primarily on the nineteenth and the early twentieth centuries, this book concentrates on Cold War-era America, and provides the foundation for the exploration of the post-Civil Rights period, the next evolutionary phase in this historical narrative.

The examination of Horne's political 'awakening' in the Introduction is significant as it reclaims the singer's legacy from the narrative of black respectability and assimilation and re-contextualizes the revolutionary nature of her musical and cinematic performances. It also uncovers the networks created throughout the twentieth century by black women entertaineractivists who sought to transfer knowledge and culture, and to encourage self-actualization. One learns that this praxis of transference is both generational and ritualized. Feldstein positions Lena Horne's activism as the model for what is realized years later in Carroll, Simone, Makeba, Lincoln, and Tyson. Horne engaged this generation of entertainer-activists in what Bernice Johnson Reagon has described as 'mothering/nurturing. ${ }^{4}$ This is a ritualized practice whereby women engage in the transference of culture and markers of identity. It is part of the natural order of the black community and is gendered in its execution. Reagon explained this as follows:

Within the African Diaspora story, there is the opportunity to see a process of continuance and transformation at work among women cultural workers. There is the struggle to contend with a new space where their people and children are defined in new ways. That definition disrupted and threw into severe trauma cultural practices that had been nursed in African societies. Mothering therefore required a kind of nurturing that would both provide food and stamina for survival within a cruel slave society and the passing on of nurturing that would allow for the development of a community that was not of but beyond the slave society. These women had to take what they were given from their mothers and fathers and make up a few things. Nurturing was not only reconciling what was passed to them with the day-to-day reality, but also sifting and transforming this experience to feed this child, unborn, this new Black community, in preparation for what it would face.

Mothering/nurturing is a vital force and process establishing relationships throughout the universe. ${ }^{5}$

3 Most notable is Jayna Brown's Babylon Girls: Black Women Performers and the Shaping of the Modern (Durham: Duke University Press, 2008).

4 Bernice Johnson Reagon, 'African Diaspora Women: The Making of Cultural Workers', Feminist Studies 12/1 (1986), 88.

5 Reagon, 'African Diaspora Women', 87-8. 
Reagon's assertions frame not only the engagement that occurs between Horne and this generation of entertainer-activists, but also exposes the methodologies through which each of these women performed civil rights: continuance and transformation. As Feldstein writes in the Introduction:

As Horne grappled with the work that a younger generation was doing, younger women performers, in turn, grappled with her legacy and ongoing presence. In direct and indirect ways, Miriam Makeba, Nina Simone, Abbey Lincoln, Diahann Carroll, and Cicely Tyson encountered the long shadow that Lena Horne cast as an icon of black female glamour and felt the impact of Horne's decades of celebrity. Like Horne, they developed performance strategies and political positions; like Horne, they were deeply concerned with how they could (or could not) represent themselves. Horne was involved as an activist-entertainer in the ' 60 s at the same time that she was a foundational figure to whom younger black women entertainers were consistently compared. The five younger stars looked to Lena Horne as a model, alternatively as what to be and what not to be. (16-17)

The remaining chapters of How It Would Feel to Be Free explore how each woman enacts the cultural praxes of continuance and transformation. While Feldstein explores this enactment thoroughly in discussions of the work of Carroll, Lincoln, and Tyson in film and television, for the sake of the remainder of this review, I will focus primarily on how the cultural praxes of continuance and transformation are explored in reference to the musical performances of Simone, Makeba, Lincoln, and Carroll. Simone's musical background included training in European classical music and, even though her aspirations to be a concert pianist never materialized, one still heard markers of this genre in her performances of Tin-Pan Alley songs, ballads, blues, and jazz standards. Makeba's engagement in the cabaret culture of South Africa provides an exciting point of comparison. While Feldstein extensively discusses Lincoln's and Carroll's engagement with music in Chapter 4 ('No One Asks Me What I Want'), the substantive and substantial musical discussion in the text is centred on Makeba and Simone.

By the time Miriam Makeba arrived in America in 1958, she was already a polished artist. Her performances at the Village Vanguard and other upscale New York venues garnered her substantial attention from critics and audiences all eager to hear authentic African songs and see authentic African beauty. From the very beginning, what seemingly framed Makeba's engagement with American audiences was her disassembling of the stereotypes regarding the primitivism of African culture and physical appearance of African women. Makeba's engagement in the praxis of continuance can be read through consideration of her performance repertoire during the late 1950s and early 1960s. Her performances of black South African music - specifically songs such as 'Wimoweh' (which was written by Zulu singer-composer Solomon Linda in the 1920s and first recorded by Linda and the Evening Birds in 1939) and her performance of the 'Boot Dance' (complete with costume) - reflected how these traditions were preserved through aural practice. Feldstein frames Makeba's process of transformation in two ways. First she considers the singer's evolution 
from being a 'passive' activist to becoming the embodiment of the black South African struggle for liberation. Second is her claim that Makeba's performances - along with her professional interactions with Odetta and Harry Belafonte - expanded the definition of folk and the folk revival to include a more Pan-African perspective. It should be noted that while the author discusses a number of specific songs in relation to their dialectic and topical aspects, there is very little analysis of the sonic elements of Makeba's performances.

It is clear, however, that the author's analytical perspective on Simone's musical performances is much more developed. Chapter 3, 'More than Just a Jazz Performer', explores many different facets of Simone's evolution, from aspiring concert pianist to entertaineractivist. The 'blossoming' of Simone's militant political voice is not solely situated in the writing of 'Mississippi Goddamn' (1963), but is also examined with regard to the gendered nature in which her temperament and performances were read by critics and audiences throughout the late 1950s and early 1960s. Feldstein efficiently outlines how hostility, rudeness, and anger are confirmed as markers of genius in male musicians such as Miles Davis, Charles Mingus, and Max Roach, but for female musicians such as Simone it is viewed as emblematic of emotional instability and behaviour that operates outside the realm of female respectability. The praxes of continuance and transformation are explored through a discussion of a selection of Simone's performances. Rather than concentrate on the totality of Simone's oeuvre from this period, Feldstein focuses on various live and recorded performances of the songs 'Mississippi Goddamn', 'Go Limp', 'Pirate Jenny', and 'Four Women'. These songs reflect the vast and diverse performance repertory that Simone drew from during her career. They are also reflective of her ability to re-contextualize lyrical content, musical setting, and the form and structure of a piece depending of use, audience, and performance context. An example of this lies in the analysis of Simone's performance of 'Pirate Jenny', a song taken from Kurt Weill's The Threepenny Opera. Simone transforms the song into a narrative of how class, race, and gender intertwine in the American South. The merging of race and gender into the larger rhetorical narrative of the Civil Rights Movement is a central theme in Feldstein's discussion of Simone's music. One noteworthy aspect of this chapter is its analysis of the reception history of Simone's 'Mississippi Goddamn' and 'Four Women'. Feldstein asserts that the problem with Simone's angry musical statements was not rooted in the accuracy of what she was communicating but rested in the realization that she was a woman publically projecting these ideals and emotions. This point is one of many revelatory and profound claims made in this text.

How It Feels to Be Free also explores briefly Abbey Lincoln's evolution from musician to actress. While Feldstein does give more attention to Lincoln's cinematic work, I do believe that some discussion should be given here of Feldstein's short exposition of her musical career. Lincoln's musical output during the late 1950s and early 1960s was varied, ranging from Abbey is Blue, her 1959 record which consisted of lyrics that spoke directly to the freedom movement, to her non-textual screams and shrieks on the landmark 1960 collaborative recording We Insist!: The Freedom Now Suite! (made with her husband, jazz drummer Max Roach). Both albums are noteworthy for various reasons. But, for Feldstein, they are particularly important as the first instances when Lincoln's consciousness as an entertainer-activist was publically 
mediated. This consciousness seems parallel to Simone's as it was decidedly more aggressive and militant in tone and lyrical content. It was in this portion of Feldstein's text that I wished more discussion had been given to the sonic elements of Simone and Lincoln's performances. The means through which each of these artists utilized the timbral aspects of their voices to convey various aspects of emotion distinguished their performance aesthetics from those of their peers. Fuller attention to the sonic would also have helped substantiate the cultural link Makeba, Simone, and Lincoln had with the praxis of continuance. The use of altered tones and guttural effects are representative of the musical practices African people developed to project emotion and ideological beliefs.

In summation, How It Would Feel to Be Free provides an important theoretical and historical discussion of how a generation of female entertainer-activists challenged gender and racial marginalization through the enactment of a variety of performance strategies. These strategies can be understood as what I term 'vocalized protest' and 'embodied protest'. Vocalized protest involves the speaking and singing voice serving as the origin of intoned or textual protest. Within this context the scream, hum, and moan can be viewed as resistance just as much as lyrics. The performances of Makeba, Lincoln, and Simone reveal that vocalized protest during the 1950s and 1960s was both overt and subtle. 'Embodied protest' is when the body is used as the means of disrupting the ethos and function of a space. In the Freedom Movement this was reflected in many ways - from sit-ins and wade-ins to marches - but Feldstein indicates how this also extended to black women's performance in recording studios, on concert stages, in film, and on television screens, ultimately redefining historical narratives of African culture and identity on the continent as well as in the New World diaspora.

TAMMY L. KERNODLE $<$ kernodtl@miamioh.edu>

Twentieth-Century Music 12/2, 279-285 ( Cambridge University Press, 2015 doi: $10.1017 / S 1478572215000092$

Brian Harker, Louis Armstrong's Hot Five and Hot Seven Recordings (New York: Oxford University Press, 2011), ISBN: 978-0-195-38841-1 (hb), 978-0-195-38840-4 (pb).

Catherine Tackley, Benny Goodman's Famous 1938 Carnegie Hall Jazz Concert (New York: Oxford University Press, 2011), ISBN: 978-0-195-39830-4 (hb), 978-0-195-39831-1 (pb).

Keith Waters, The Studio Recordings of the Miles Davis Quintet, 1965-68 (New York: Oxford University Press, 2011), ISBN: 978-0-195-39383-5 (hb), 978-0-195-39384-2 (pb).

Peter Elsdon, Keith Jarrett's The Köln Concert (New York: Oxford University Press, 2012), ISBN: 978-0-19-977925-3 (hb), 978-0-199-77926-0 (pb).

Gabriel Solis, Thelonious Monk Quartet Featuring John Coltrane at Carnegie Hall (New York: Oxford University Press, 2014), ISBN: 978-0-199-74435-0 (hb), 978-0-199-74436-7 (pb).

Beyond popular press reviews and criticism, iconic jazz recordings have recently become objects of scholarly investigation. Inasmuch as live performance is so celebrated (and even 